\title{
4
}

\section{Technological Advancement and Long-Term Economic Growth in Asia}

Jeffrey D. Sachs and John W. McArthur

\subsection{Introduction}

We are living in an age of remarkable technological change that is forcing us to think very hard about the linkages between technology and economic development. The harder we think about it, the more we realize that technological innovation is almost certainly the key driver of long-term economic growth. We further realize that the innovation process must be supported by a complex set of social institutions. Although markets have a great deal to do with innovation, innovation is not purely a market-driven phenomenon. Innovating economies require an interconnected set of market and nonmarket institutions to make the innovation process work effectively, and for this reason, governments need an innovation strategy if they wish to foster highly innovative economic systems.

This need for an innovation strategy is as real in Asia as it is anywhere else in the world. In Asia, however, the necessity is perhaps more immediate than in most other developing regions, since many Asian economies now stand at a threshold of development requiring a new approach to technology and growth. Over the next twenty-five years, many Asian economies will undergo a transition from being top-flight adopters of 
technologies from the United States, Europe, and Japan, to becoming technology innovators.

This chapter outlines in broad terms the rationale for a focus on systems of innovation, with particular emphasis on the challenges facing East Asian economies. Following this introduction, section 4.2 briefly outlines the modern theory of economic growth, focusing on the main lessons regarding the role of technology in economic development. We relate the theory to the most notorious modern example of an economy without technological advance, the Soviet Union, as well as to Latin America, a region that has also generally paid insufficient heed to the importance of technological advance. Section 4.3 discusses the distinct processes of innovation and diffusion, and describes Asia's place in the current global technological divide. Section 4.4 then emphasizes several key traits of the innovation process and section 4.5 describes the notable successes of the U.S. innovation system in this light. Section 4.6 highlights some lessons for Asia as the region's economies progress toward innovation-based growth in the years ahead, and section 4.7 concludes.

\subsection{Economic Growth Theory and the Role of Technology}

Economic theory offers a series of textbook approaches to understanding economic change. One of the first was initiated in 1776 by Adam Smith (Smith 1981), who emphasized the role of the division of labor in promoting rising output per person. He stressed that increasing specialization, mediated mainly by market forces, would lead to rising efficiency in production, and therefore to rising living standards. Smith focused on the role of market institutions, efficiency in transactions, and effective property rights in promoting high levels 
of economic well-being. Understandably, Smith's model of the division of labor did not draw primary attention to innovation since he was living at the time when the Industrial Revolution was just gaining force. The full import of sustained innovations across many economic sectors could still not be seen.

Much of modern growth theory was developed in the middle part of the twentieth century, when a series of pathbreaking papers - including those by Roy Harrod (1939), Evsey Domar (1946), and particularly Robert Solow (1956) and his followers - led economists to stress savings, investment, and capital accumulation as key drivers of gross national product levels and growth. The practical implication was that, based on these and a few other key theoretical foundations, development economists around the world directed their policy advice toward ways to raise the savings rate in an economy and on ways to channel savings into productive investments. Much less attention was paid to the part of economic growth that is founded upon technological change.

There is a certain irony to the focus on capital accumulation, since Solow's pathbreaking 1956 neoclassical model, the one that won him a Nobel Prize in 1987, actually had a contrary message, as Solow himself indicated. The Solow approach remains the first economic growth model that students learn, usually presented with a focus on the rise in capital per person as the prime force in raising living standards over time. Yet Solow showed that when the saving rate rises in an economy, this leads to a temporary increase in the rate of capital accumulation and a permanent increase in the level of output per capita, but not to a rise in the long-run rate of growth of output per capita. The long-term economic growth rate in Solow's model is actually independent of the rate of saving and capital accumulation. Indeed, in order to produce a sustained rate of 
growth in his model, Solow had to go beyond mere capital accumulation. He had to introduce an exogenous rate of improvement in labor productivity, presumably the result of technological advancement. But in his famous model, Solow did not try to explain the source of that technological advancement; he merely assumed it.

A year after his 1956 theoretical piece, Solow made a basic and tremendously important calculation that is still instructive for scholars today (Solow 1957). He examined U.S. economic data from 1909 to 1949 and asked what they tell us about the sources of U.S. economic growth over that period of time. Ingeniously, he used his theoretical framework to extract the part of economic growth that was due to more capital accumulated per person from the part that was due to the advance of technology. These were the first such national growth accounting calculations in the modern study of economics.

What did Solow find? He found that technological change accounted for seven-eighths of the growth of the U.S. economy and that increases in capital stock - the equipment, machinery, and residential stock relative to the population-accounted for only one-eighth of the growth of income per person in the United States. His empirical assessment supported the theoretical suggestion of his model that technological advancement has been the key long-term driver of economic development.

Those two articles in 1956 and 1957 had an extremely important message: Understanding long-term economic growth requires understanding technological innovation. But the economics profession is somewhat odd. The technically challenging part of the Solow growth models lies in solving a differential equation for how fast the capital stock grows rather than in interpreting the mysterious process of technological change. And so, for the many years following Solow's initial contribu- 
tions, economists studied the role of savings and investment as the central feature of economic growth, rather than focusing on the sources of long-term technological change. This began to change only in the 1980 s.

\subsubsection{What Happens When There is No Technological Advancement?}

Joseph Stalin provided the most compelling example of trying to use a high saving rate as the key to economic development when he promoted forced saving, in a very brutal manner, to promote industrialization in the Soviet Union. Yet the Soviet economy had very little technological change in the civilian sector for decades and, as a result, came about as close as possible to a case of a high saving rate combined with stagnant technology. It is probably fair to say that it proved a key result of the Solow model nicely, albeit in a planned-economy context: Capital accumulation without technological advancement eventually leads to the end of economic growth.

In the beginning of forced industrialization in the 1930s, the Soviet economy grew quite rapidly as the marginal productivity of new capital investments in industry was high. The Soviet planners in the 1930s and afterward allocated industrial investments according to the industrial division of labor that they copied from the United States and Germany at the time. They calculated how many steel mills and coalmines and so forth were needed to build an automobile sector or an airplane industry and then built up those industries in fixed proportions over time. The division of labor was rigidly set. Capital accumulation increased the scale of production without affecting dramatically the division of labor. New innovations were difficult or impossible to introduce into the rigid planning structure, other than in the military sector. 
The Soviet planners contributed to a national tragedy, but an instructive historical episode for the world, by pursuing the capital accumulation process with little civilian technological change for half a century. They proved that by accumulating capital in the absence of technological change, the marginal productivity of capital is driven down to essentially zero. By the 1970s and 1980s, the Soviet Union was producing more steel in the aggregate than the United States, for example, even though its income level was less than a third of the U.S. level. But by that time the ability to turn the vast quantities of steel into higher output per capita had almost disappeared. As a result, the Soviet Union became a giant steel graveyard, with rusting steel everywhere.

Although not characterized by a high savings rate, some South American economies, most notably Argentina, provide another example of what can happen when a region does not progress technologically. Thirty years ago, much of South America was at an admirable level of income per capita by global standards. Most of the region has stagnated economically since then. There are many different explanations as to why. The standard ones involve things like bad macroeconomic management, unstable governments, and high inflation. However, many of these explanations are more symptoms than fundamental causes. At the root of the problem, it appears, is the low emphasis on long-term technological advancement and innovation.

In the 1960s and 1970s, many economies in South America probably became quite comfortable, and perhaps even complacent, with the wealth provided by natural resource exploitation. Hence they failed to make the transition to technological innovation as the basis for development. Even today, high-income and sophisticated economies like Argentina show 
very little technological innovation. Argentina produces many world-class scientists, but too many of these end up working in Boston or Palo Alto rather than in Buenos Aires. This is in part because there has been no national strategy to promote technological advancement through domestic innovation.

In sum, the failure of traditional development economics in many countries where capital accumulation was the core focus highlights the need for long-term technological advancement to sustain economic growth. An economy without technological innovation, even if it has an extremely high national savings rate like China's, will not avoid stagnation unless it continually advances its technological capacity. To do so systematically, one needs to understand the process of developing and applying new ideas in production.

\subsection{Innovation and Diffusion: Asia Today in Relation to the World's Technological "Core"}

Fortunately, since the early 1980s growth theory and development theory have increasingly analyzed the process of technological innovation as a central feature of growth rather than as something that was simply "brought in" from the outside. Major contributions were made by Lucas (1988), Romer (1990), Grossman and Helpman (1991), and Aghion and Howitt (1992), among many others. Today, the goal is to understand the transition from technological change as an "exogenous" feature of an economy to technological change as an "endogenous" feature. Broadly, the aim is to understand how a society produces technological advance.

Theoretical models stress that there are two basic modes of advancing technology. One is innovation (developing one's own new technologies) and the other is adoption (introducing 
technologies that have been devised elsewhere). Of course, all economies pursue both modes to some extent, and there is no doubt that every economy produces only a modest fraction of the technologies that it uses. Adoption of technology from abroad is sufficient to raise living standards substantially, and even to achieve long-term growth based on the continuing technological innovations achieved abroad. But technology adoption has its limitations as well.

Economic theory demonstrates that if one economy is a technological innovator while another economy is a technology adopter, the innovator will maintain a lead in income per capita relative to the adopter. The income gap between the two economies persists over time even though the technology adopter ends up incorporating all of the technological advances made by the innovator. It does so, but only with a lag, and the persisting lag in technology translates into a persisting gap in income levels in favor of the innovator. The relative income ratio, or degree of "catch-up" between the innovator and the adopter, depends on the relative rates of innovation and diffusion of technology (where diffusion signifies the rate at which innovations are absorbed by the adopting economy). The lessons from this kind of model of innovation and adoption are twofold. First, a follower economy that adopts technology from abroad but that does not innovate itself will always lag behind the innovator. Second, even technological adoption requires specialized institutions that facilitate the diffusion of new technologies.

This pattern of enduring income gaps between technological innovators and adopters is not just a theoretical construct. In background research for the most recent Global Competitiveness Report (McArthur and Sachs 2002), we have found strong empirical evidence suggesting the limits to technological 
diffusion as a source of growth and the need for economies to progress beyond adoption to innovation if they want to continue to close the gap with the highest-income countries. This evidence is of great importance to many East Asian economies today, given their current stage of economic development. Our colleague Andrew Warner $(2000,2002)$ has also shown empirically that countries differ markedly in their capacities to innovate and to adopt technologies. Some countries, including many in Asia, are effective adopters of technology while displaying little innovation to this point.

Indeed, it is fair to say that East Asia has been the most successful region in the developing world in adopting technologies from the innovating economies. This is in part because East Asia developed ingenious institutions for quickly adopting technological advances from abroad. For example, the electronics and semiconductor production throughout Southeast Asia and coastal China is based on technology that came from the United States and Japan originally thirty years ago. The East Asian developing countries created special economic zones, export processing zones, science parks, and other institutional arrangements to entice foreign investments in the electronics sector who were looking for low-cost places to produce their products. Thanks to the success of these specialized institutions, East Asia became one of the key global centers for new electronics industries during the past three decades. Thus, even though the technology was originally developed in Palo Alto and environs, it diffused very quickly to East Asia. The diffusion was so fast that it allowed a substantial narrowing of the income gap of East Asia with the United States. But, as the formal growth models suggest, rapid technological diffusion by itself did not, and will not, fully close the income gap. Full catching up will require that East Asia become a major innovator in its own right. 
Much of Asia, with roughly two-thirds of the world's population, is currently in the middle of an historic transition from being a technological adopter to becoming a center of innovation as well. Japan made that transition many decades ago. To understand where the rest of Asia needs to go technologically, it is instructive to consider which parts of the world are currently technological innovators, as opposed to technological adaptors. In doing so, one quickly finds one of the most striking facts of the world economy today: The places that are true technological innovators-in that they are creating new processes or new products, commercializing them, and bringing them to market-form a small part of the world's population. If we look at the amount of patenting as one indicator of innovation (with patents providing a rough measurement of the rate of commercialization of ideas), it turns out that the top ten patenting countries in the world, with less than 13 percent of the world's population and 69 percent of the world's gross national product (GNP), account for 94 percent of all patents taken out in the United States. ${ }^{1}$ The top twenty patenting countries in the world, with less than 15 percent of the world's population and 77 percent of its GNP, account for 99 percent of the all current patenting in the United States.

These figures illustrate the astoundingly high concentration of technological activity in the world today. In no sense is innovation a globally dispersed process with all regions contributing to the advancement of knowledge in roughly proportionate terms, or even in terms proportionate to income levels. Instead, the global divide in technology is even starker than the divide in income. Only a few parts of the world are high innovation countries. Another bloc of the world, with roughly 2 billion people, including the 1.3 billion in China, consists of 
effective adopters of technology from abroad. A third category of countries, with perhaps as much as half the world's population, is neither innovating nor particularly successful at adopting technologies developed abroad. This largest group doesn't attract foreign investors in high-tech fields; and it can't make effective use of technologies developed abroad because it lacks something - the engineers, the scientists, the local market size, or the ecological characteristics-required to use the new technologies effectively.

The three-tiered global divide in technological capacitythose that are innovating at a high rate, those that are adopting at a high rate, and those that are largely excluded from the process of technological advancement-is also the major driver of the world's widening gaps in income over long periods of time. The countries that are falling farther and farther behind the world's leaders in income are the technologically excluded countries. The countries in the middle that are technological adopters-like so much of East Asia over the past forty years, other than Japan-often grow even faster than the leaders for a period because once they create good systems for diffusion of technology, they can enjoy a period of rapid but incomplete catching up.

Consider the U.S. patent data in more detail. In 2000, the U.S. Patent and Trademark office granted 85,072 patents to inventors in the United States. Japanese inventors were awarded 31,296 patents, the second-highest number among all countries. Germany ranked third with 10,234 patents. If one puts that in terms of patenting per million population, which gives a useful measure of the intensity of innovative activity in the economy, the United States had 309 patents per million population, Japan 247 patents per million population, and Germany 124 patents per million population. 


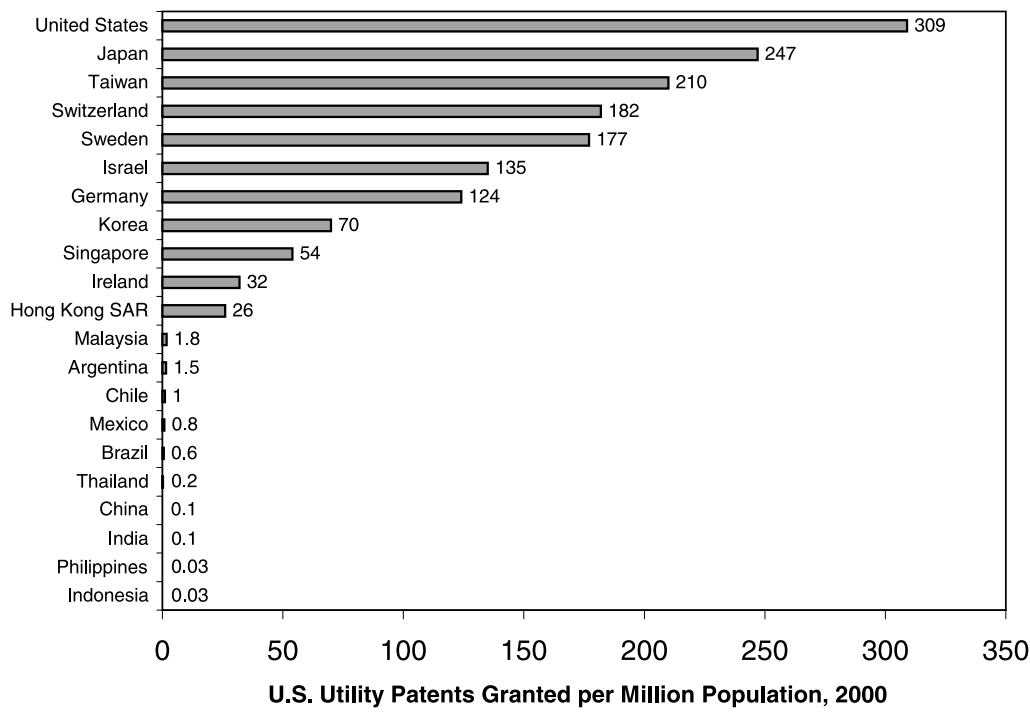

Figure 4.1

Patents per capita in 2000: Asia compared to other selected economies.

Source: U.S. Patent and Trademark Office 2001.

As shown in figure 4.1, there are two Asian economies other than Japan that are notable for having made the transition from adoption to innovation during the last twenty-five years: Taiwan and Korea. (The other developing country to do so over the same period was Israel, which last year registered 783 patents, or 135 per million people.) These are the two countries that exhibited a dramatic rise in the rate of scientific and patenting activities and today both stand out as being among the world leaders in innovative activity. Korean inventors, for example, received 3,314 patents last year in the United States, a rate of 70 patents per million population-not as high as in the United States, Germany, or Japan, but very respectable 
in global terms. Taiwanese inventors received 4,667 patents in the United States in the year 2000, or 210 patents per million, which ranks third in the world on a per capita basis. Further behind stand Hong Kong and Singapore, somewhere in the middle between innovators and non-innovators. Last year Hong Kong inventors had 179 patents in the United States, or 26 per million people. Singapore had 218, or 54 per million people. Probably no economies absorb technology faster and better than Hong Kong and Singapore. But these economies are not yet great engines of scientific advance.

What about China? China had 119 patents in the United States in the year 2000 , so that is 0.1 patent per million, or 1 patent for every 10 million in the population. While China is the fastest-growing economy in the world and its coastal zones have been enormously successful in bringing in technologies and producing increasingly sophisticated exports, China is not yet really an innovating economy. While there are astoundingly fine scientists around the country, it remains difficult in the Chinese system to transfer the basic science developed in the Chinese Academy of Sciences into commercializable products that are marketed in the world economy.

In Southeast Asia, Indonesia received 6 patents last year for its 224 million people, or less than 3 per 100 million population. Malaysia had 42 patents taken out in the United States, or 1.8 patents per million. Thailand had 15 patents, again less than 3 per every 10 million population. The Philippines had 2 patents, or less than 3 per 100 million population. These patenting data provide one measure of Southeast Asia's current status in terms of endogenous growth. Basically, endogenous growth there is nonexistent; no commercializable science-based technological advance is taking place in this region today. 
Referring to the South American context for a moment, the U.S. patent data highlight the weakness of the region regarding technological innovation. In the year 2000, Argentina had 54 patents or only 1.5 patents per million population, which was slightly more than Chile at 1.0 per million population and Brazil at 0.6 per million. In other words, even the most developed economies in South America are currently in a technological position similar to much of Southeast Asia. Notably, however, in 1960 Argentina was roughly five times richer than Southeast Asian economies in terms of per capita GNP. Despite its relative wealth, Argentina failed to make a transition to technological innovation, as did other countries in South America. The lesson must not be lost for the economies of East Asia.

\subsection{Characteristics of the Innovation Process}

A high rate of innovation requires a mix of market and nonmarket institutions, with the mix reflecting the nature of the innovation process. There are several basic characteristics of this process that we would highlight.

First, innovation is science based. This implies a great deal of importance for higher education as a fundamental feature of a national innovation strategy. Critically, higher education does not take place anywhere in the world without a major investment by government.

Second, innovation is an increasing returns to scale process, which means that ten scientists isolated on ten separate desert islands will produce much less scientific and technological progress than the ten scientists stuck together on one island. That is why scientists like to congregate in islands or valleys like Silicon Valley or Route 128. This is also why we have 
universities-because it is helpful for scientists to talk to each other so that they can develop good ideas with the help of the person next door. Creating an innovation system requires creating scale.

Third, innovation depends on market-based incentives, and most importantly on the scope of the market itself (just as Adam Smith emphasized in regard to the division of labor). Paul Romer and others have put great stress on the importance of the scope of the market in promoting innovation. Developing a new idea requires a significant onetime investment of research and development $(\mathrm{R} \& \mathrm{D})$, and this "fixed cost" of innovation must be recouped through subsequent sales. If the potential market for the innovation is large, it is obviously easier to recoup the one-time R\&D expenses. A small market, on the other hand, will not justify the high onetime costs of R\&D. That is one reason why it is vital to be an open economy. When an economy is export oriented, it has the whole world as a potential market. A closed economy, on the other hand, will not only fail to get new ideas from outside, but will also not generate incentives for innovation based on a limited domestic market.

Fourth, and vitally, there is a fundamentally mixed public and private good nature to the innovation process. A central characteristic of knowledge is what economists call "nonrivalness," which means that if one person discovers a new idea (such as a new scientific discovery) and shares it with others, the idea isn't lost to the first person. Ideas are not like a barrel of oil or a ton of steel, where use of the commodity by one person means that less is available for others. With ideas, everybody can partake of the advancement of knowledge without depriving others of the knowledge. This nonrivalness has a critical implication. Society benefits through the wide- 
spread diffusion of ideas. To this end knowledge-based economies aim at the free and broad distribution of basic scientific knowledge, new mathematical theorems, and the like.

There is of course a major problem with the free dissemination of knowledge: Discoverers may lack a financial incentive to make their discoveries in the first place if their ideas will be freely available throughout the society. For this reason, scientists are encouraged by social status, fame, and prizes, as well as by direct market incentives. They are also encouraged by the temporary monopoly privileges granted by a patent to a new invention. But patents are imperfect instruments for giving incentives to make new discoveries. Patents offer financial benefits to the inventor for a temporary period (now generally 20 years from the date of filing) but limit the ability of others in the society to make use of the knowledge.

In the face of these tensions, innovative societies have found the following pragmatic compromises. Basic scientific discoveries, in general, are not patentable. They are to be freely available for use throughout society. Patents are limited to specific new technologies. Also, patents are given for a limited period of time, so that eventually the knowledge can be freely used throughout society. The costs of permanent monopoly rights in slowing the diffusion of new ideas would be too great. Meanwhile, governments support basic scientific discovery through direct subsidization of primary research in universities, government research laboratories, and even private companies that qualify for government grants.

Fifth, special financing mechanisms beyond the banking sector help to accommodate knowledge creation in the private sector. A lot of knowledge is intangible and noncollateralizable. Banks often won't lend to people with good ideas because the banks require collateral to guarantee loans. With 
new ideas there is frequently no collateral available. This is what makes venture capital a distinctive industry. Venture capital is not lending against collateral, but against someone's hope that the technology is going to work commercially. That is not what bankers do for a business, nor is it what one would want banks to do because banking has other risky features that require tight regulation. Thus, since banks do not and should not lend mainly for noncollateralized ideas, the innovation process requires somebody else who will: venture capitalists.

Sixth, innovation generates destruction of older technologies and business sectors in a process Joseph Schumpeter ([1942] 1984) famously termed "creative destruction." New advances are not painless to those using and producing older technologies. Thus, economic death of old sectors is part and parcel of the advance of new sectors. One of the reasons that the Soviets could never develop a new industry is that they never let an old one die. There really was lifetime employment protection (other than for the millions sentenced to the gulag). Although people could lose their jobs (and indeed sometimes their lives) for political reasons, they did not lose their job for economic reasons. With no sectors ever declining, no new sectors could ever grow.

Seventh, the innovation process is characterized by specific forms of organization that develop, test, and prove ideas. Innovation first requires networks to bring different kinds of knowledge together. It also requires a great deal of risk taking and decentralization within larger enterprises to allow entrepreneurs within the firm to be entrepreneurial. It furthermore requires a great deal of learning. The most advanced innovation systems are comprised of enterprises investing heavily in their workers' knowledge, which is not a traditional activity in many economies. 
Eighth, many technologies exhibit characteristics of site specificity, which means if you want to solve problems in agriculture, health, energy use, and so forth, local ecological characteristics are so important that the relevant problems need to be solved at home. Not all technologies can be adopted from abroad, which is another reason why the technological adopters stay behind the technological leaders: Much of what the technological leaders are producing is not necessarily relevant to the adopter's needs if the local ecological settings are quite different. If U.S. inventors develop new processes for raising wheat productivity, that may have little direct benefit for cassava growers in Africa. Local needs require local innovations in many sectors.

\subsection{The U.S. Economy as an Innovation System}

These eight characteristics of the innovation process lead to several practical implications for the design and operation of national systems of innovation. We illustrate this basic idea by looking at how the United States has achieved such high and sustained rates of innovation. Part of the story of course is that the U.S. economy is large, integrated, and efficient. A large scope of the market provides a large incentive for innovation. Yet the story is more complicated. Specific institutions, both market and nonmarket based, are integral to U.S. success.

First, the United States invests intensely in basic science through the federal budget. Many believe that the United States is a free market economy in the technology realm, but this is not true. The U.S. government budget for science is now roughly \$US 90 billion a year, or almost 1 percent of GNP. Biomedical research alone is supported at a rate of around $\$ 25$ billion per year. One needs to understand that U.S. industrial 
policy is quite consciously focused on science-based technological growth, even though many observers believe that that the United States has no industrial policy. In the late 1980s, when the U.S. government was worried about Japanese competition, it financed major investment in the semiconductor sector to advance its technology. More recently, the government has invested heavily in the human genome project and nanotechnology, among other leading sectors.

Second, the United States has demonstrated and championed the agglomeration economies that have been achieved most prominently in Silicon Valley, the research triangle of North Carolina, and Route 128 in the Boston area, but also in dozens of other locations around the United States. ${ }^{2}$

Third, the United States has a rather effective patent system, even though it is a system under stress at this moment. When an inventor files a patent, he or she has to disclose in detail what the new invention entails, in return for the patent's monopoly rights. That is extremely important in making the knowledge publicly available. The system is also effective at processing a huge numbers of patents, now more than 150,000 per year. The judicial system has considerable expertise in protecting intellectual property after the patent is granted. Still, the system is under considerable stress regarding the appropriate scope of patenting, the definition of the boundaries of new patents, and the sheer volume of new patent applications to process.

Fourth, the United States also has a very effective interface between government, universities and industries, and these connections have been honed experimentally over the last twenty-five years. As one important part of the process, the Bayh-Dole Act of 1980 enabled universities to receive patents on new inventions that were developed with government 
grants, thereby giving new incentives to academic centers to support applied R\&D activities, and to collaborate with the private sector in R\&D. That gave a tremendous boost, most notably in biotechnology, to university-business collaboration in the innovation process.

Fifth, the United States has a highly advanced regulatory environment in many areas. In agro-biotechnology, for instance, the Food and Drug Administration (FDA), the U.S. Department of Agriculture, and the Environmental Protection Agency (EPA) have all set high regulatory standards contributing to food product safety. These high standards have given consumers a large amount of confidence in technological change. The United States has not yet had the kind of backlash to innovation in agro-biotechnology that has occurred in Europe, so its innovation has not been stifled as it has been in Europe. The solid and credible regulatory structure has helped fuel the innovation process in these areas. Regulation can thereby promote technology, even though some free market economies resist it.

Sixth, the United States has an extremely strong network of venture capital financing that is closely interwoven with the key regional nodes of technological innovation. The infrastructure and tax systems both support venture capital, based on an understanding that normal banking will not create the needed financing for technology start-ups.

Seventh, the United States has a flexible labor market, which means that a lot of people lose their jobs so that a lot more can get new ones. It is an economy utterly typified by creative destruction. Net job creation is ferociously successful, something Europe hasn't yet caught on to.

Eighth, the administrative environment is tremendously conducive to new business start-ups. To start a business, one 
basically needs only to write a small check to the state government to register the new company. This fosters an incredibly dynamic process of natural selection of small businesses. Millions of new ventures and ideas are tried each year. Only a small fraction of these survive, but that small fraction may go on to do wonderful things.

Ninth, and finally, the United States now has a stupendously effective higher education system, with extremely high participation rates. The country's gross tertiary enrollment rate is estimated to be 81 percent (World Bank 2001), which means that overall postsecondary enrollment is equal to four-fifths of the university age population. This is an imprecise measure of university enrollment, since it includes students of all ages at major research universities, smaller liberal arts colleges, specialized vocational training centers, and community colleges, but it does indicate the huge number of Americans attending college in one form or another. And even with the imprecision of the measure, it is vastly higher than the same figure in most other parts of the world.

\subsection{Some Lessons for Asia's Transition from Technology Borrower to Core Innovator}

Altogether, these factors make the U.S. system extraordinarily dynamic technologically. They also help to shed some light on Asia's current challenges in moving from technological borrower to technological innovator. Of these challenges, the following stand out.

First, and most critically, higher education is probably going to be the region's most strategic investment for the next generation. Tertiary enrollment rates in Asia are still rather low, as shown in figure 4.2. In China the tertiary enrollment 


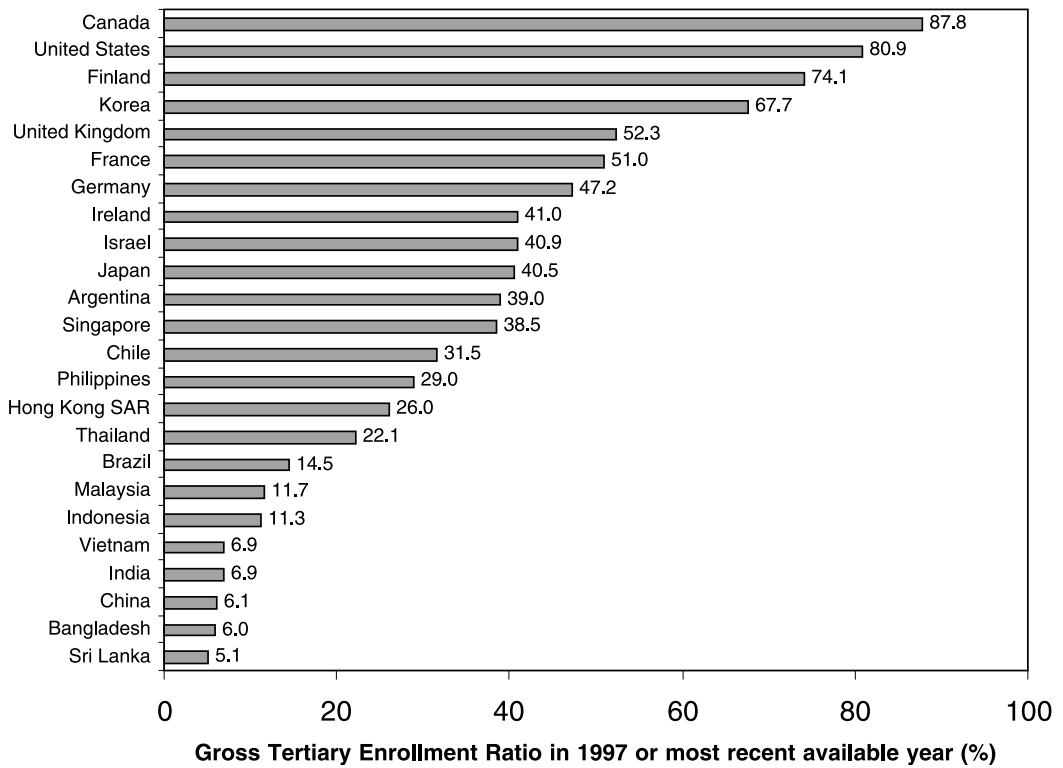

Figure 4.2

Tertiary enrollment rates in Asia compared to other selected economies

Source: World Bank 2001; World Bank and UNESCO Task Force on Higher Education and Society 2000.

rate (according to World Bank data) was just 6 percent in the mid-1990s. In Indonesia it was roughly 11 percent, and in Malaysia it was just under 12 percent. Hong Kong was considerably higher at 26 percent, as was Singapore at 39 percent. All of these rates have no doubt increased in the past few years, but they still lag far behind the enrollment rates in higher education seen in the technologically innovative economies.

A second challenge is to increase government spending on science. This does not imply indiscriminate investment in, for example, theoretical physics, but it does imply investment in areas that are relevant for an economy and its society. Korea, 
Taiwan, and Israel are examples of countries that, thirty years ago, consciously decided invest substantial government revenues in building world-class laboratories in order to support research at universities and to facilitate $R \& D$ in the private sector. After a generation of investment, they have seen enormous returns. Today, they are continuing down this path of science-based growth, with all three currently rank among the top fifteen in the world in terms of total R\&D spending as a percentage of gross national product, and all allocating roughly two percent or more of their national incomes to research (World Bank 2001). These spending ratios are somewhat ahead of Singapore, which spends in the neighborhood of 1.1 percent of GNP on R\&D, and China, which spends roughly 0.7 percent of GNP. All of these figures are significantly better than those for Indonesia, Malaysia, and the Philippines, which each spend less than one quarter of one percent of GNP on R\&D.

A third challenge, and related to the first two, is to foster university-business relations for new startups and technological innovation in key areas. In survey results calculated for the latest Global Competitiveness Report 2001-2002 (GCR) (World Economic Forum 2002), Singapore, Taiwan, and Korea are the only Asian countries to score among the top twenty on a question that asks executives to rate the level of local university-business collaboration. Japan scores 26th, China 28th, India 38th, Malaysia 42nd, Indonesia 45th, and the Philippines 55th. This dimension represents a key development area for most Asian economies.

Fourth, an effective intellectual property rights system is needed. At the core of this issue rests the need for the rule of law and an effective, independent judiciary to protect of intellectual property rights. Many Asian countries do not have 
judicial systems that are independent from political pressures or from the parties in a dispute, let alone intellectual property rights regimes. Again citing the latest GCR results, on a composite measure of institutional strength in "contracts and law," most Asian economies fare poorly. Singapore scores among the world's top ten countries, but Malaysia, for example, scores 42nd while China ranks 51st and Philippines ranks 56th, two spots ahead of Indonesia. More specifically, on a survey question that asks about the protection of intellectual property, Singapore, Japan, Taiwan, and Hong Kong rate between 15th and 25th, while Thailand and Malaysia rank in the mid-forties and India, China, the Philippines, and Indonesia rank no better than 58th. Legal institutions are by no means easy to develop but they mark a crucial challenge in the long-term development of most Asian economies and thus need to be on this list.

Fifth, economies in the region need to improve the administrative conditions for business startups. As figure 4.3 shows, some Asian economies are performing well in this respect, but even Japan needs to do more in this area. Japan is remarkably technologically innovative but it is not nearly as good at bringing innovations to market. One of the reasons is the difficulty of starting a business in Japan today. In a GCR survey question that asks executives to rank the overall ease of starting a business locally, Hong Kong ranks first in the world, Singapore ranks 6th, Thailand places 17th, China 23rd, Japan $32 \mathrm{nd}$, and Korea 49th. Another reason, one that still poses a key challenge in much of Asia, is that the venture capital market is thin. In a GCR survey question on the availability of venture finance for innovative but risky ideas, Taiwan, Singapore and Hong Kong rank 13th, 14th, and 16th, respectively, 


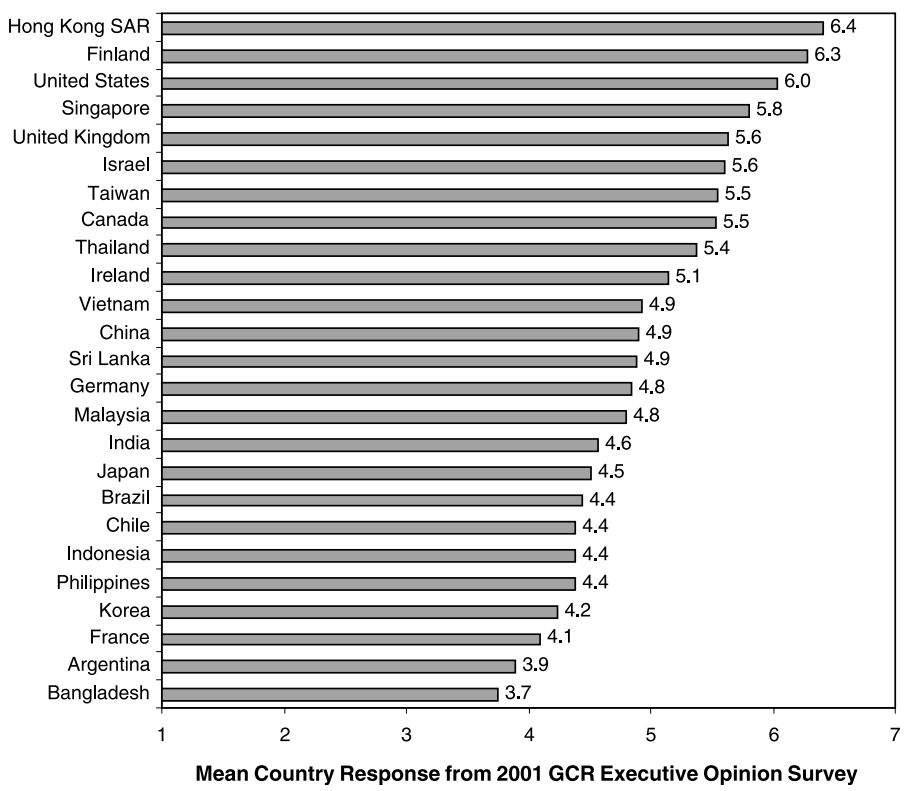

\section{Figure 4.3}

Administrative Burden for start-ups: "Starting a new business in your country is generally: $(1=$ extremely difficult and time consuming, 7 = easy)"

Source: World Economic Forum 2002.

but Japan ranks 31st, China scores 49th, the Philippines ranks 50th, and Thailand places 51st. Private finance mechanisms for innovation need to be a key priority in these economies.

A sixth challenge lies in the structure of business enterprises in Asia. Innovative firms require special conditions of internal organization, including a high degree of delegation of authority within enterprises, productivity-based compensation, and internal learning mechanisms within the firm. Figure 4.4 shows the GCR results for a question regarding the typical amount of 


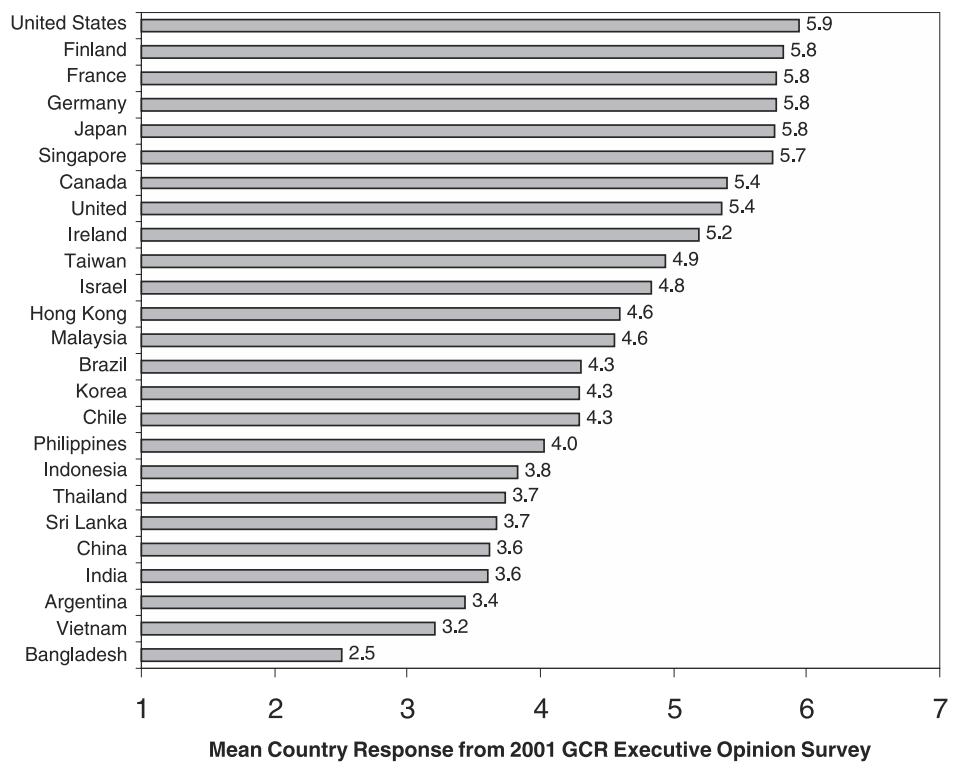

Figure 4.4

Firm investments in staff training: 'In your country, companies' general approach to human resources is to invest $(1=$ little in training and development, $7=$ heavily to attract, train, and retain staff)" Source: World Economic Forum 2002.

firms' internal investment in staff training. Notably, Singapore and Japan rate well at a global scale but much of Asia still lags far behind. This and related evidence suggest that many of the organizational forms and corporate practices in Asia are not particularly advantageous for high rates of organizational learning and innovation.

In practical terms, the exact transition pathway for an economy hoping to move from a successful diffusion system to a successful innovation system is not fully known, but together the six points mentioned help to highlight key areas on which 
many Asian economies must focus. Undoubtedly this list is not exhaustive, and there is much room for economies to innovate in creating systems of innovation. But, at a minimum, policy priorities need to mix market and nonmarket forces to develop sound innovation-oriented education, research, finance, regulatory, and business structures.

\subsection{Conclusion}

A central finding of economics over the past fifty years has been that technological advancement is critical to long-term economic growth. More recent research distinguishes between the crucial roles for technological diffusion in the catch-up phase of economic development and innovation once economies reach a fairly high level of development. Asia's great challenge in this regard is to move from adoption to innovation as the engine of technological advancement. Yet the social systems that best foster technological innovation do not come into existence without an explicit effort to create them.

Creating a successful innovation system is a challenge that requires focus, attention, and institutional creativity. There is no doubt that Asia has everything that it needs to become a central site of science-based innovation in the twenty-firstcentury world economy. This chapter has highlighted some of the issues it must face in achieving this aim. As the region progresses, we predict that one of twenty-first-century's biggest transitions will occur when both China and India begin to make dramatic contributions to global science and technology and thereby dramatic contributions to the welfare of the world. When this happens, the structure of the world economy will change in new and promising ways. 


\section{Notes}

This chapter was originally presented as a speech by Professor Jeffrey D. Sachs on May 25, 2001, as part of the Technology and the Economy Lecture Series at Hong Kong University.

1. According to United States Patent and Trademark Office's 2001 data. The U.S. Patent and Trademark Office record the country origin of a patent according to the country of residence of the first-named inventor. Note that the data refer to "utility patents," that is, patents for new inventions.

2. Our colleague Michael E. Porter has provided ongoing leadership in advancing the mapping and understanding of U.S. business clusters, as discussed, for example, in his article "Clusters and the New Economics of Competition." See Porter 1998.

\section{References}

Aghion, Philippe, and Peter Howitt. 1992. "A model of growth through creative destruction." Econometrica 60 (March): 323-351.

Domar, Evsey D. 1946. "Capital expansion, rate of growth, and employment." Econometrica 14 (April): 137-147.

Grossman, Gene M., and Elhanan Helpman. 1991. Innovation and Growth in the Global Economy. Cambridge, MA: The MIT Press.

Harrod, Roy F. 1939. "An essay in dynamic theory." Economic Journal 49 (June): 14-33.

Lucas, Robert E. Jr. 1988. "On the mechanics of economic development." Journal of Monetary Economics 22 (July): 3-42.

McArthur, John W., and Jeffrey D. Sachs. 2002. "The growth competitiveness index: Measuring technological advancement and the stages of development." In The Global Competitiveness Report 20012002, ed. Michael E. Porter, Jeffrey D. Sachs, et al. New York: Oxford University Press.

Porter, Michael E. 1998. "Clusters and the new economics of competition." Harvard Business Review (November-December): 77-90.

Romer, Paul M. 1990. "Endogenous technological change." Journal of Political Economy 98 (October): S71-S102. 
Schumpeter, Joseph A. [1942] 1984. The Theory of Economic Development. Cambridge: Harvard University Press.

Solow, Robert. 1956. "A Contribution to the theory of economic growth.” Quarterly Journal of Economics 70 (February): 65-94.

Solow, Robert. 1957. "Technical change and the aggregate production function." Review of Economics and Statistics 39 (August): 312320.

Smith, Adam. [1776] 1981. An Inquiry into the Nature and Causes of the Wealth of Nations. Indianapolis: Liberty Press.

U.S. Patent and Trademark Office. 2001. "Patent counts by country/ state and year: Utility patents, January 1, 1963-December 31, 2000." Available on-line at $\langle$ http://www.uspto.gov/ $\rangle$.

Warner, Andrew M. 2000. "Economic creativity." In The Global Competitiveness Report 2000, ed. Michael E. Porter, Jeffrey D. Sachs, et al. New York: Oxford University Press.

Warner, Andrew M. 2002. "Economic creativity: An update." In The Global Competitiveness Report 2001-2002, ed. Michael E. Porter, Jeffrey D. Sachs, et al. New York: Oxford University Press.

World Bank. 2001. World Development Indicators 2001 CD-ROM. Washington, DC: The World Bank.

World Bank and UNESCO Task Force on Higher Education and Society. 2000. Higher Education in Developing Countries: Peril and Promise. Washington, DC: The World Bank.

World Economic Forum. 2002. The Global Competitiveness Report 2001-2002, ed. Michael E. Porter, Jeffrey D. Sachs, et al. New York: Oxford University Press. 